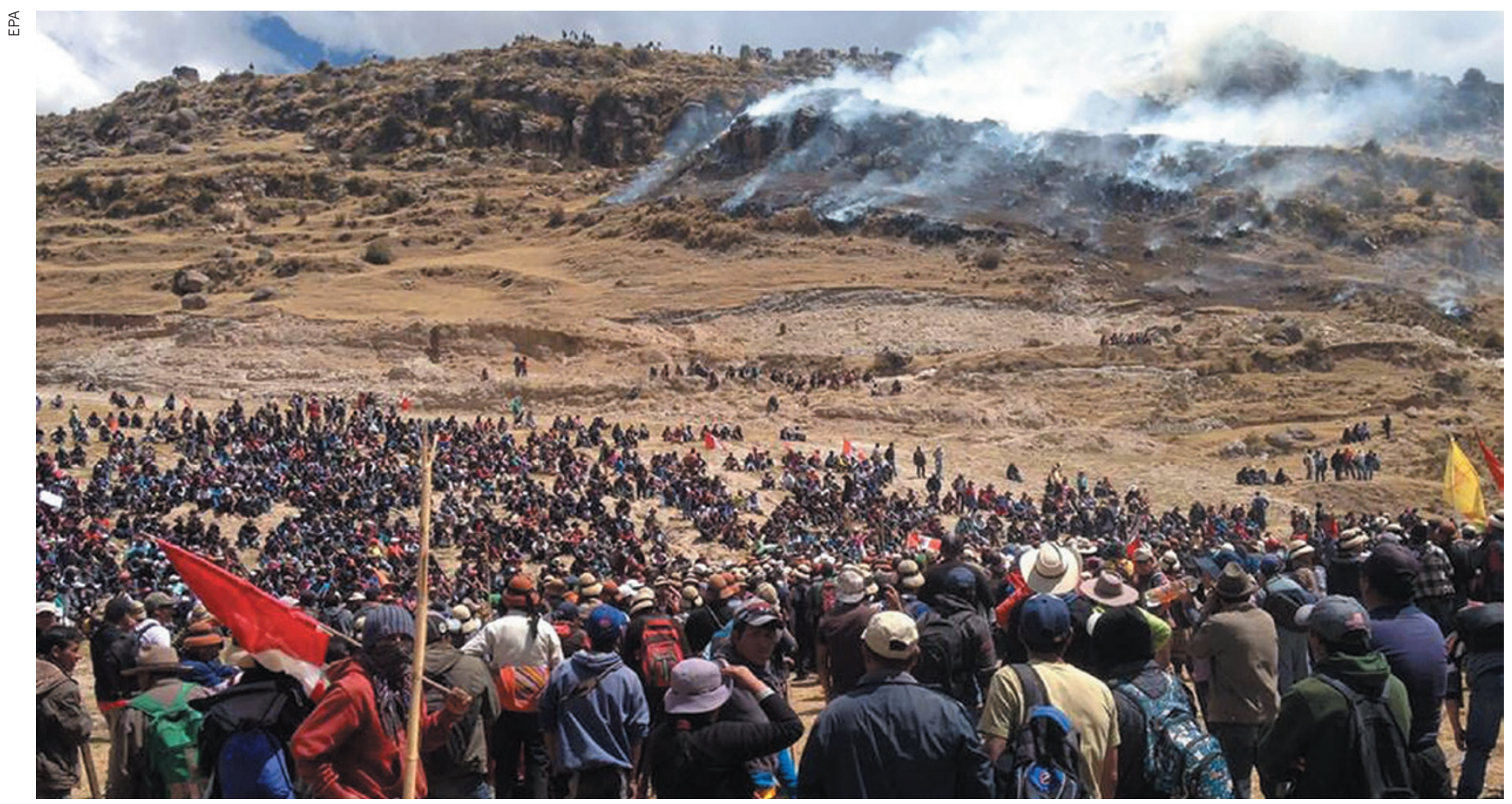

Protests against China's Las Bambas mining project in Peru erupted into violence last year.

\title{
ECONOMICS
}

\section{China in the new world}

\section{Margaret Myers on a study of the impacts of the country's presence in Latin America.}

$\mathrm{F}$ or nearly 15 years, China's economic and construction boom, coupled with high commodity prices, has driven soaring demand for steel, copper and other commodities. Latin America has been a crucial partner, with Chile, for instance, accounting for $40 \%$ of raw copper imports and Brazil responsible for $49 \%$ of soya imports. China's mounting concerns about food and energy security have also prompted engagement with resourcerich Venezuela, Peru and Argentina. The China-fuelled 'super-cycle' has left a path of environmental destruction and social conflict in Latin America. Now, China's economic slowdown and a slump in commodity prices spell bleaker economic prospects for exporting nations. For instance, Chilean copper company Codelco announced massive layoffs in 2015 as copper prices dropped.

As one of the first accounts of post-"China boom” Latin America, Kevin Gallagher's The China Triangle adds much to a profusion of books on China-Latin America relations. By skilfully framing Latin America's development challenges - such as lack of highly skilled labour - in a historical context, Gallagher reminds us that commodity-led growth is hardly a new phenomenon in the region. The end of the nineteenth century saw the first boom, when Europe and the United States began to import raw materials in serious quantities. Years of dependence on exporting natural resources led to wide-ranging policy outcomes in Latin America, from stateled industrialization to the Washington Consensus, a set of US prescriptions for eco-

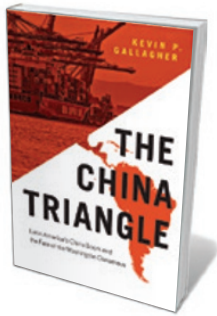

The China Triangle: Latin America's China Boom and the Fate of the Washington Consensus KEVIN P. GALLAGHER Oxford University Press: 2016. nomic development in the region in the 1990s and 2000s. The China Triangle is largely premised on the idea that the most recent phase in Latin America's economic development was as much a rejection of the consensus as an embrace of China.

As Gallagher shows, that relationship has been rocky in many ways. Gallagher documents the negative effects of booming trade and investment by Chinese and other firms in extraction of natural resources. Growth in mining alone has led to increased chemical leaching, improper disposal of waste and acidic runoff from mines. Chemical leaching has killed fish and caused economic damage in Peru. Deforestation and related flooding in Argentina are thought to stem from the rise in soya production for export to China.

Gallagher is careful to note that Chinese companies have shown their capacity to adapt to Latin American laws and norms. In Peru, US company Doe Run performed much worse on a number of counts than Chinese mining firms. But the vast majority of trade, $90 \%$ of Chinese investment in Latin America and $80 \%$ of its loans to the region's governments are focused in sectors linked to environmental degradation. Hence China has, on average, more environmental impact in Latin America than do other partners.

Concerns surround China's hydroelectricdam projects in the region, including the Coca-Codo Sinclair dam, Ecuador's largest energy project. Although this is expected to address a critical energy deficit, many Ecuadoreans are concerned about water diversion from the San Rafael Falls, a prominent tourist destination, and the construction of access roads in the Amazon. The Néstor Kirchner 
and Jorge Cepernic dams in Argentina were touted as key energy projects by former president Cristina Fernández de Kirchner, but they are far from the grid and about 2,750 kilometres from Buenos Aires, where energy needs are high. A 2006 feasibility study of 30 dam projects by Argentina's energy ministry ranked them 23rd and 25th, respectively.

In 2015, Chinese company MMG Ltd modified its environmental-impact study for the Las Bambas copper-mining project in Peru's Cotabambas province without consulting local communities. Although compliant with newly modified Peruvian law, the decision provoked demonstrations by local residents that ended in 4 deaths and led Peruvian President Ollanta Humala to declare a 30-day state of emergency in the province.

Despite China's slowing growth and some bad press, the country will - Gallagher reveals - remain one of the region's key economic partners. Last year saw Chinese finance to Latin America and the Caribbean rise to a level surpassed only in 2010, much of it focused on oil, gas and transport infrastructure. Just as US investors did in the decades straddling the turn of the last century, China is seeking to develop transport networks to carry commodities to port, such as the Peru-Brazil railway proposed during Chinese Premier Li Keqiang's 2015 visit to the region.

Latin America also stands to benefit from China's sustained presence. In The Dragon in the Room (Stanford University Press, 2010), Gallagher and Roberto Porzencanski advised nations to capture China's windfall by investing in export diversification. They did not, but Gallagher insists in The China Triangle that it is not too late. He prescribes greater partnerships between countries and markets, and policies that promote equality and environmental stewardship. But postboom, Gallagher foresees a Latin America with less room to manoeuvre, economically and politically. The region would need to appeal to both the United States and China to ensure future growth. Gallagher's 'China triangle' refers to this shift.

The value of diversified partnerships, whether with the United States and China or a wider variety of partners, is increasingly clear to Latin Americans. The region should avoid dependency on rawmaterials exports - and beware of reliance on big powers with deep pockets.

Margaret Myers is director of the China and Latin America programme at the Inter-American Dialogue, a Western Hemisphere affairs think tank in Washington DC.

e-mail:mmyers@thedialogue.org

\title{
Glass half full
}

\author{
Stuart Pimm examines E. O. Wilson's grand vision for \\ an Earth shared equally between humanity and nature.
}

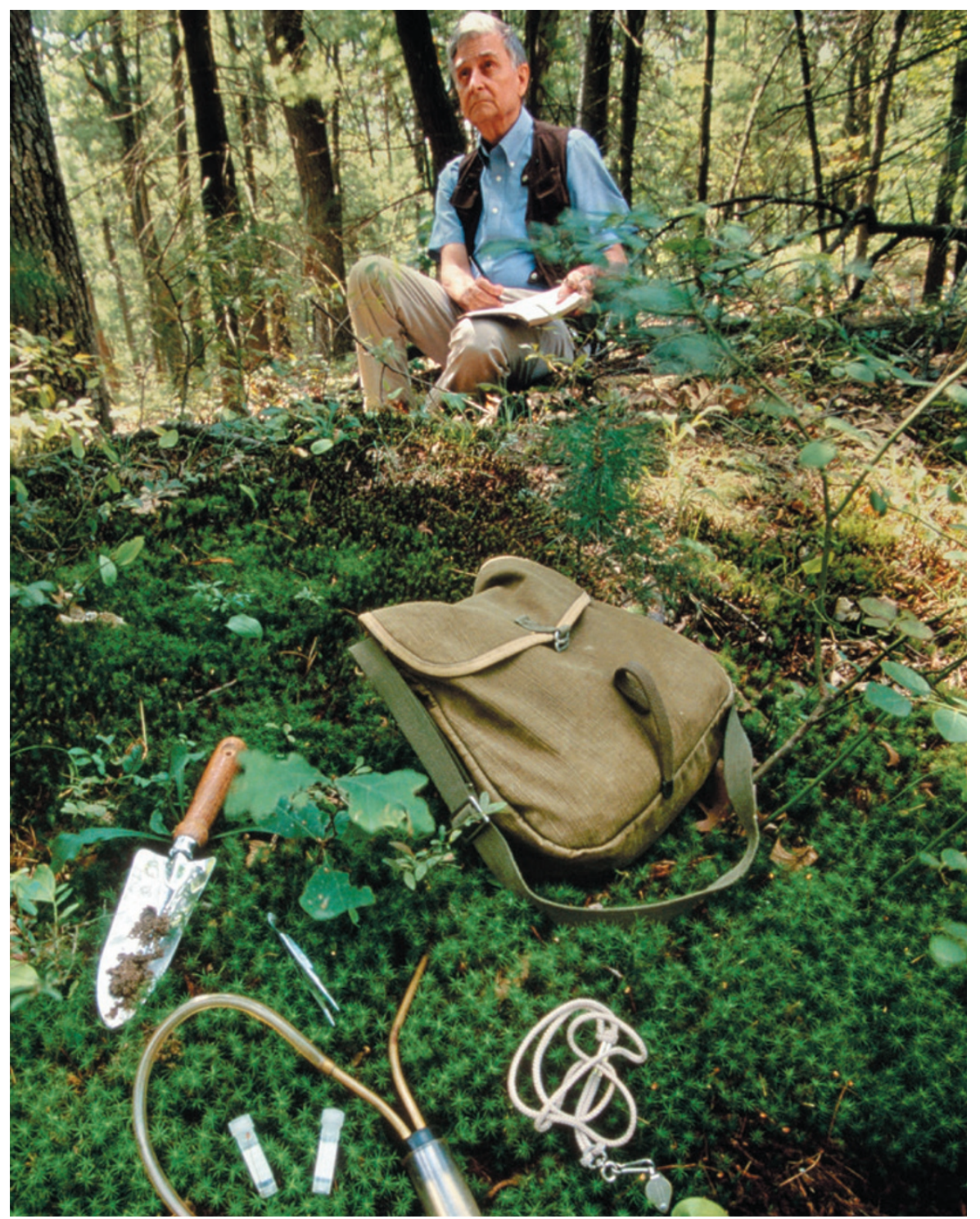

Biologist E. O. Wilson suggests a radical approach to conservation.

W hat do humans want? So asks E. O. Wilson near the start of Half-Earth, his bold vision for the biosphere. He outlines the probable answer: "indefinitely long and healthy life for all, abundant sustainable resources, personal freedom, adventure both virtual and real on demand, status, dignity, membership in one or more respectable groups, obedience to wise rulers and laws, and lots of sex with or without reproduction". He adds: "These are also the goals of your family dog."

The eminent biologist demands that we aspire to much more. He calls for no less than committing half of the planet's surface to a haven for nature. It's an ambitious goal, yet failure would be dire.

This is no isolated argument. Half-Earth is the last in a trilogy. In The Social Conquest of Earth (Liveright, 2012), he marvels at how advanced social organization is rare among animals and how "one species of large-sized African primate" - us - has become not merely dominant, but a force of geological change. In The Meaning of Human Existence (Liveright, 2014), he argues that we are 